\title{
EFEKTIVITAS PEMBELAJARAN DARING BAGI GURU MADRASAH IBTIDAIYAH DI MASA PANDEMI COVID-19
}

\author{
Minzani Aufa ${ }^{1}$, Kanthi Pamungkas Sari ${ }^{2}$ \\ ${ }^{1,2}$ Pendidikan Guru Madrasah Ibtidaiyah, Universitas Muhammadiyah Magelang \\ Jalan Mayjend Bambang Soegeng, Mertoyudan, Magelang, Jawa Tengah \\ ${ }^{1}$ e-mail: minzaniaufa@ummgl.ac.id
}

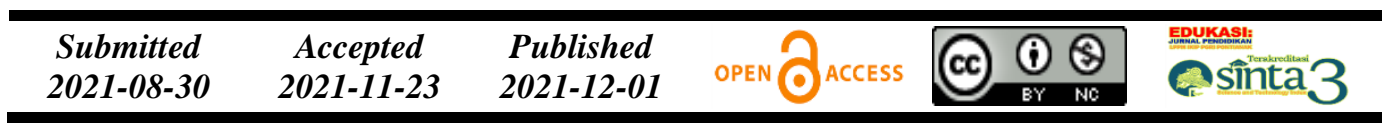

\begin{abstract}
Abstrak
Tujuan penelitian adalah untuk menganalisis efektivitas pembelajaran daring bagi guru madrasah ibtidaiyah (MI) se-Kota Magelang. Metode penelitian yang digunakan adalah deskriptif kualitatif. Sumber data dan informasi utama diperoleh dari subjek penelitian dengan populasi sebanyak 31 orang yang terdiri dari 29 guru dan 2 kepala madrasah. Teknik pengumpulan data menggunakan observasi, dokumentasi, wawancara, dan angket. Teknik analisis data menggunakan analisis deskriptif. Berdasarkan hasil penelitian disimpulkan bahwa: pembelajaran daring di MI se-Kota Magelang selama masa pandemi COVID-19 berjalan secara "efektif"; guru telah menjalankan pembelajaran daring saat pandemi COVID-19; guru dapat menguasai "smartphone" dan "laptop" sebagai tool dalam pembelajaran daring; "WhatsApp" merupakan pilihan utama sebagai media dalam melaksanakan pembelajaran daring; dan guru "setuju" jika pembelajaran daring dilanjutkan dengan memperhatikan rencana pelaksanaan pembelajaran daring (RPPD) yang telah dibuat sesuai dengan indikator yang telah terukur sesuai dengan capaian pembelajaran.
\end{abstract}

Kata Kunci: analisis efektivitas; COVID-19; guru MI; pembelajaran daring.

\begin{abstract}
The research aimed to analyze the effectiveness of online learning for madrasah ibtidaiyah (MI) teachers throughout Magelang City. The research method used descriptive qualitative. The main sources of data and information were obtained from research subjects with a population of 31 people consisting of 29 teachers and 2 madrasah principals. Data collection techniques used observation, documentation, interviews, and questionnaires. The data analysis technique used descriptive analysis. Based on the results of the research, it was concluded that: online learning at MI in Magelang City during the COVID-19 pandemic was running "effectively"; teachers have been running online learning during the COVID-19 pandemic; teachers can master "smartphones" and "laptops" as tools in online learning; "WhatsApp" is the main choice as a medium in carrying out online learning; the teacher "agrees" if online learning is continued by paying attention to the online learning implementation plan (RPPD) that has been made in accordance with indicators that have been measured in accordance with learning outcomes.
\end{abstract}

Keywords: effectiveness analysis; COVID-19; MI teacher; online learning. 


\section{PENDAHULUAN}

Perkembangan teknologi informasi mendorong munculnya bermacammacam inovasi di bidang pendidikan dalam model pembelajaran. Penerapan model pembelajaran dengan menggunakan teknologi mulai banyak bermunculan disebabkan adanya hambatan-hambatan saat proses pembelajaran berlangsung (Anugrahana, 2020; Lesmana \& Arpan, 2017; Sii et al., 2017), terutama di masa pandemi COVID-19 (Huzaimah \& Amelia, 2021; Hariyanti et al., 2020; Marken, 2020). Pandemi COVID-19 yang terjadi dapat mengancam keselamatan jiwa seseorang, sehingga proses pembelajaran tidak bisa berlangsung melalui tatap muka (Sutini et al., 2020). Dampak pandemi COVID-19 pada proses pembelajaran cukup terasa, hal tersebut terlihat dari kegiatan belajar-mengajar yang seharusnya dilakukan secara langsung, sekarang hanya bisa dilaksanakan mandiri oleh siswa secara daring.

COVID-19 yang tidak menentu kapan selesainya membuat rakyat terus menjadi resah. Hal tersebut juga dirasakan oleh guru madrasah ibtidaiyah (MI). Guru MI dengan penuh kerja keras mempersiapkan seluruh kebutuhan pembelajaran daring. Guru diharapkan mampu menjalankan aktivitas pembelajaran selama masa pandemi COVID-19, walaupun siswa belajar dari rumah. Seorang guru dituntut agar dapat berinovasi untuk mengonsep media pembelajaran daring. Hal tersebut sebagaimana yang disampaikan dalam Surat Edaran Mendikbud Nomor 4 Tahun 2020 tentang Kebijakan Pendidikan dalam Masa Darurat Penyebaran COVID-19 yang intinya bahwa pembelajaran yang disampaikan melalui daring diselenggarakan dengan optimal, supaya dapat memberikan pengalaman belajar yang lebih bermakna kepada siswa, dengan tidak terbebani menyelesaikan semua target capaian kelulusan dan/atau kenaikan kelas.

Tidak setiap guru mampu dengan cepat dan cermat dapat menerima dan mengolah pembelajaran sesuai kondisi objektif siswa (Riyana, 2019). Kreativitas guru saat proses pembelajaran daring merupakan poin penting untuk mencapai tujuan pembelajaran. Namun, akan lebih baik jika ada kerja sama dengan piihakpihak terkait dalam pembelajaran. Hasil penelitian sebelumnya menunjukkan bahwa implementasi pembelajaran daring pada pendidikan dasar selama pandemi 
Edukasi: Jurnal Pendidikan, Volume 19 Nomor 2 Tahun 2021

Efektivitas Pembelajaran Daring bagi Guru Madrasah Ibtidaiyah.......

Minzani Aufa, Kanthi Pamungkas Sari

Halaman 187-200

COVID-19 dapat tersampaikan dengan baik dan juga relatif dapat memberikan hasil pembelajaran yang baik pula jika terdapat kerja sama yang berarti antara guru, orang tua, dan siswa (Dewi, 2020). Hal tersebut berarti bahwa pembelajaran daring dapat memberikan dampak positif yang tidak pernah terjadi sebelumnya. Dampak positif tersebut terjadi terhadap siswa, guru, dan orang tua yang bersamasama mencapai tujuan pembelajaran.

Proses pembelajaran daring yang diselenggarakan oleh guru-guru MI di Kota Magelang juga mengalami dinamika yang menarik. Berbagai teknik dan media pembelajaran yang tepat mengalami proses trial and error. Awal pandemi COVID-19 merupakan masa ketidakpastian proses pembelajaran akan dilakukan. Satu sisi harus memutus penyebaran COVID-19 sehingga harus menyelenggarakan pembelajaran daring tetapi keterampilan dan fasilitas belum mendukung secara optimal. Beragam platform dicobakan dalam pembelajaran daring sebagai ikhtiar untuk menyesuaikan dengan berbagai kodisi. Kondisi yang dimaksud adalah kondisi guru, orang tua, dan siswa sehingga terjadi kerja sama diantara ketiganya demi tercapai tujuan pembelajaran. Pembelajaran daring idealnya menjembatani kebutuhan belajar siswa, supaya bisa meningkatkan minat dan bakat sesuai dengan tingkat pendidikan masing-masing. Dibutuhkan kesiapan seorang guru, kesesuaian kurikulum, tersedianya sumber belajar, serta daya dukung jaringan yang normal sehingga komunikasi guru dengan siswa dapat efektif dan efisien (Nurrita, 2018).

Keadaan pembelajaran daring yang terjadi belum bisa disebut sempurna karena masih ada kendala yang dialami dan belum terselesaikan. Kendala tersebut merupakan tantangan dalam menerapkan pembelajaran daring, mengingat aktivitas pembelajaran senantiasa bisa terselenggara walaupun terjadi darurat pandemi COVID-19. Kendala yang dialami dalam penerapan pembelajaran daring di MI se-Kota Magelang antara lain kesiapan guru, kurang jelasnya arahan pemerintah daerah, belum terdapatnya kurikulum yang sesuai, keterbatasan daya dukung teknologi, dan jaringan internet. Berdasarkan permasalahan-permasalahan yang terjadi, maka penelitian bertujuan untuk menganalisis efektivitas pembelajaran daring bagi guru-guru MI se-Kota Magelang. 


\section{METODE}

Metode penelitian menggunakan deskriptif kualitatif. Sumber data dan informasi utama diperoleh dari subjek penelitian dengan jumlah populasi sebanyak 31 orang yang terdiri dari 29 guru dan 2 kepala madrasah dengan rincian yang terlihat di Tabel 1.

Tabel 1 Subjek Penelitian

\begin{tabular}{lcc}
\hline \multicolumn{1}{c}{ Madrasah } & Kepala Madrasah & Guru \\
\hline MI Muhammadiyah Harapan Kota Magelang & 1 & 20 \\
MI Al Iman Kota Magelang & 1 & 9 \\
\hline
\end{tabular}

Alat pengumpulan data yang digunakan dalam penelitian yaitu observasi, wawancara, angket, dan dokumentasi. Observasi digunakan untuk mengumpulkan data sarana dan prasarana fisik madrasah yang digunakan terkait dengan proses pembelajaran. Kisi-kisi observasi terlihat di Tabel 2.

Tabel 2 Kisi-Kisi Observasi

\begin{tabular}{ll}
\hline \multicolumn{1}{c}{$\begin{array}{c}\text { Aspek yang } \\
\text { Diobservasi }\end{array}$} & \multicolumn{1}{c}{ Indikator } \\
\hline $\begin{array}{l}\text { Pembelajaran } \\
\text { daring }\end{array}$ & $\begin{array}{l}\text { Hal-hal yang diperlukan sebelum pembelajaran daring; } \\
\text { Proses pembelajaran daring oleh siswa dan guru; } \\
\text { Kondisi guru pada saat proses pembelajaran daring; } \\
\text { Hal-hal yang dilakukan guru setelah pembelajaran daring. }\end{array}$ \\
$\begin{array}{l}\text { Komponen bahan } \\
\text { pembelajaran }\end{array}$ & Bentuk dan variasi materi daring. \\
$\begin{array}{l}\text { Sarana dan } \\
\text { prasarana }\end{array}$ & $\begin{array}{l}\text { Tersedianya akses internet dan alat penunjang pembelajaran } \\
\text { daring (laptop, smartphone, komputer, jaringan internet, } \\
\text { kuota, dan lainnya). }\end{array}$ \\
\hline
\end{tabular}

Wawancara digunakan untuk memperoleh data tentang potensi permasalahan dan kelebihan dalam pelaksanaan pembelajaran daring. Subjek wawancara yaitu guru MI dan kepala madrasah. Angket digunakan untuk mendapatkan informasi data tentang efektivitas pembelajaran daring kepada guru-guru MI, mulai dari implementasi RPPD, akses, dan kejelasan instruksi evaluasi sampai pada hasil pembelajaran. Kisi-kisi wawancara dan angket terlihat pada Tabel 3. 
Tabel 3 Kisi-Kisi Wawancara dan Angket

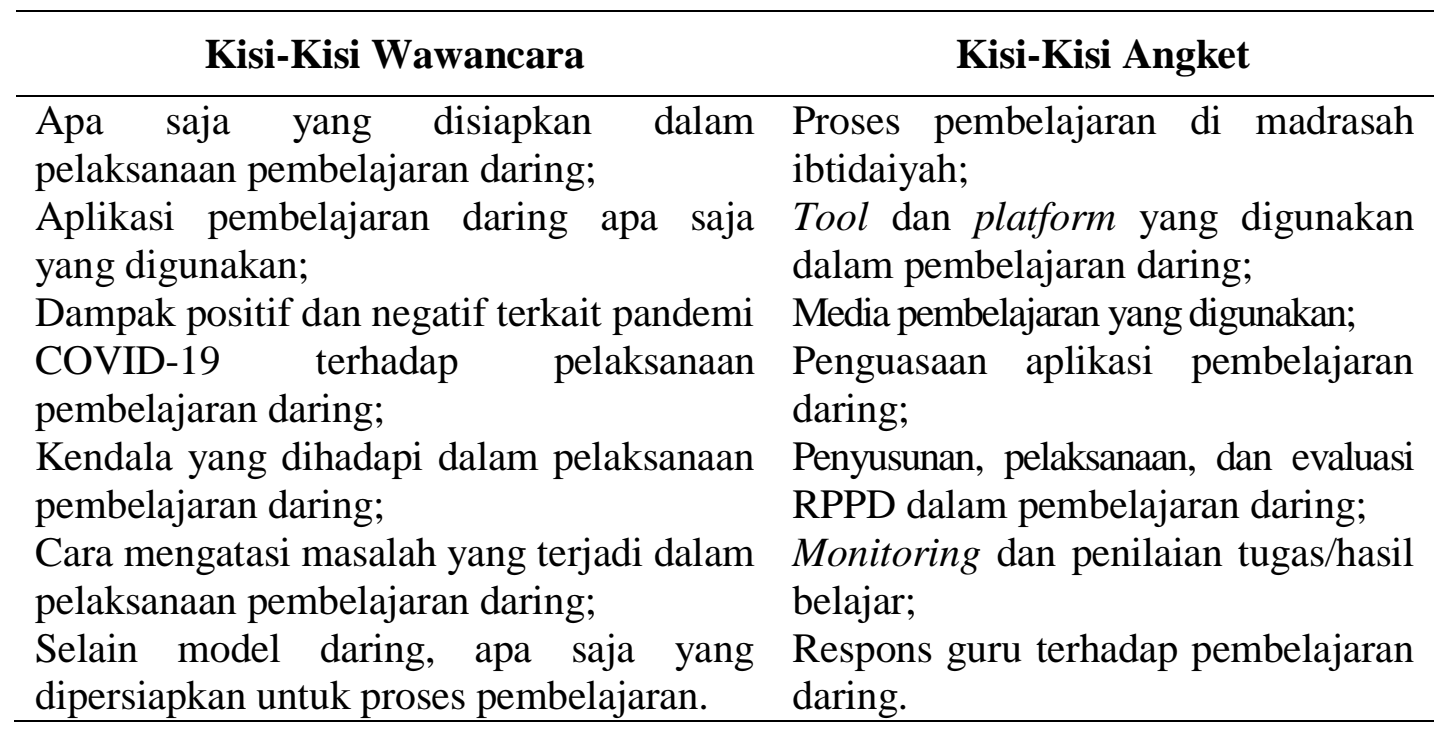

Dokumentasi digunakan untuk mengumpulkan data tentang rekam jejak kegiatan yang akan dan telah dilaksanakan dalam pembelajaran daring. Dokumentasi yang digunakan yaitu RPPD, data keadaan tenaga pendidik dan kependidikan, data keadaan siswa tahun 2020/2021, keadaan sarana/prasarana, dan keadaan geografis wilayah Kota Magelang. Teknik analisis data menggunakan analisis deskriptif kualitatif. Aktivitas dalam analisis data, yaitu data reduction, data display, conclusion drawing/verification seperti terlihat di Gambar 1 (Miles \& Huberman, 1994).

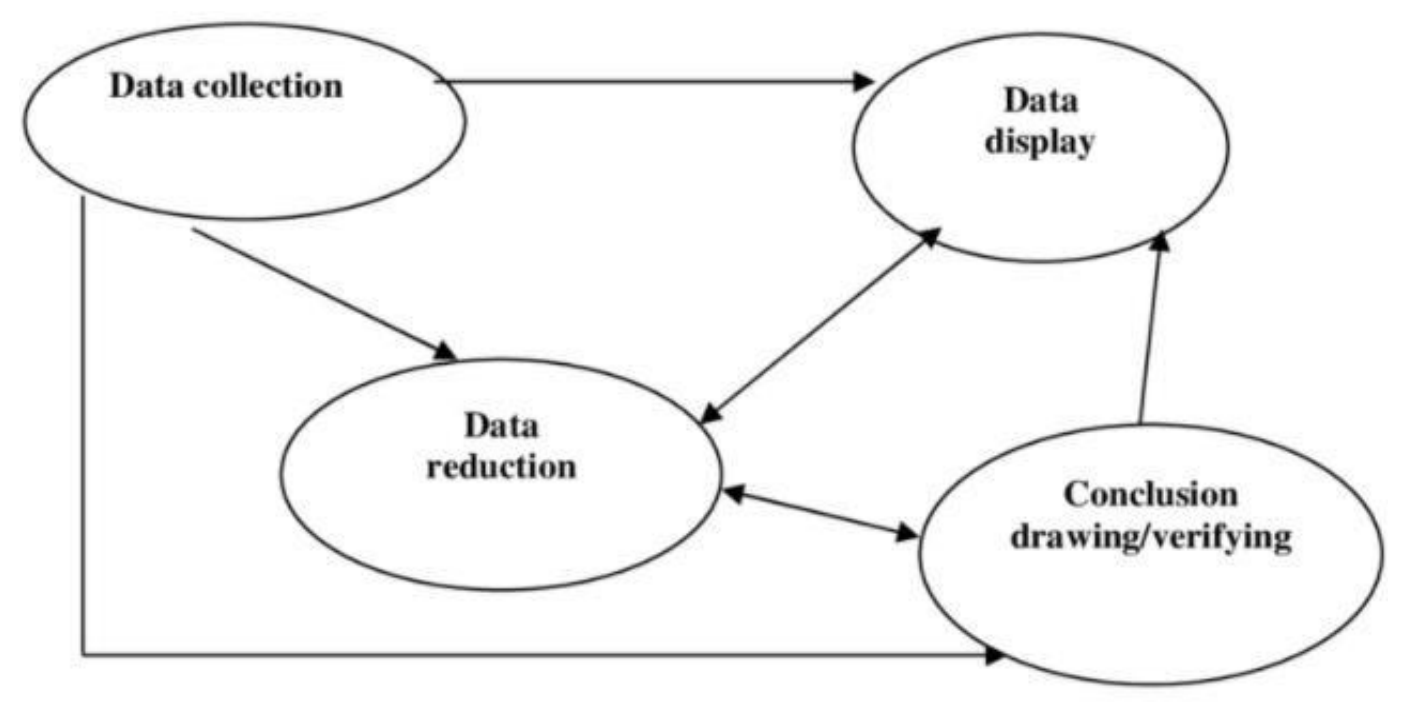

Gambar 1 Model Interaktif Miles dan Huberman 


\section{HASIL DAN PEMBAHASAN}

Ketidaksiapan siswa, guru, dan orang tua saat pembelajaran daring merupakan suatu masalah yang perlu menjadi perhatian bersama. Berubahnya sistem belajar tatap muka menjadi sistem daring sangat cepat, tidak melalui persiapan yang baik. Semua kegiatan belajar-mengajar harus berjalan meskipun pandemi COVID-19 melanda, dengan harapan siswa juga dapat belajar dengan aktif. Keguncangan pembelajaran daring sangat jelas terlihat seperti yang dialami oleh Madrasah Kami (hasil wawancara, 2 April 2021). Suatu hal yang bersifat urgen dalam pembelajaran daring ialah stabilnya sistem jaringan internet, kemudian perangkat lunak seperti komputer, laptop, dan smartphone sebagai penunjang kegiatan belajar-mengajar, serta kesiapan guru untuk menguasai berbagai aplikasi pembelajaran daring.

Berkaitan dengan pelaksanaan pembelajaran daring di MI se-Kota Magelang, guru harus tetap memperhatikan aspek-aspek perkembangan siswa. Banyak sekali tantangan dalam pembelajaran daring. Guru MI memiliki beban dan tanggung jawab penuh terhadap proses pembelajaran, sehingga kualitas pembelajaran daring harus selalu ditingkatkan. Seorang guru diharapkan selalu berkomunikasi dengan orang tua supaya pembelajaran daring dapat berjalan sesuai dengan tujuan pembelajaran. Diharapkan guru bisa lebih inovatif dan kreatif dalam memilih metode pembelajaran yang tepat dan sesuai sehingga siswa selalu bersemangat untuk belajar.

Berdasarkan jawaban responden tentang proses pembelajaran daring di MI terlihat bahwa dalam pelaksanaannya ada yang menggunakan daring dan ada yang menerapkan blended learning yang dapat dilihat pada Gambar 2. Tidak semua guru MI dalam proses pembelajarannya menerapkan daring saja, akan tetapi juga melakukan pembelajaran blended learning. Terlihat data sebanyak $68 \%$ guru MI se-Kota Magelang menggunakan pembelajaran daring dan sebanyak $32 \%$ guru di MI se-Kota Magelang menerapkan pembelajaran secara blended learning. Berdasarkan hasil tersebut, maka disimpulkan bahwa pembelajaran daring dan blended learning adalah pilihan yang dapat diterapkan dalam proses pembelajaran 
di masa pandemi COVID-19, sehingga siswa dapat ikut belajar dengan aktif dan bersemangat.

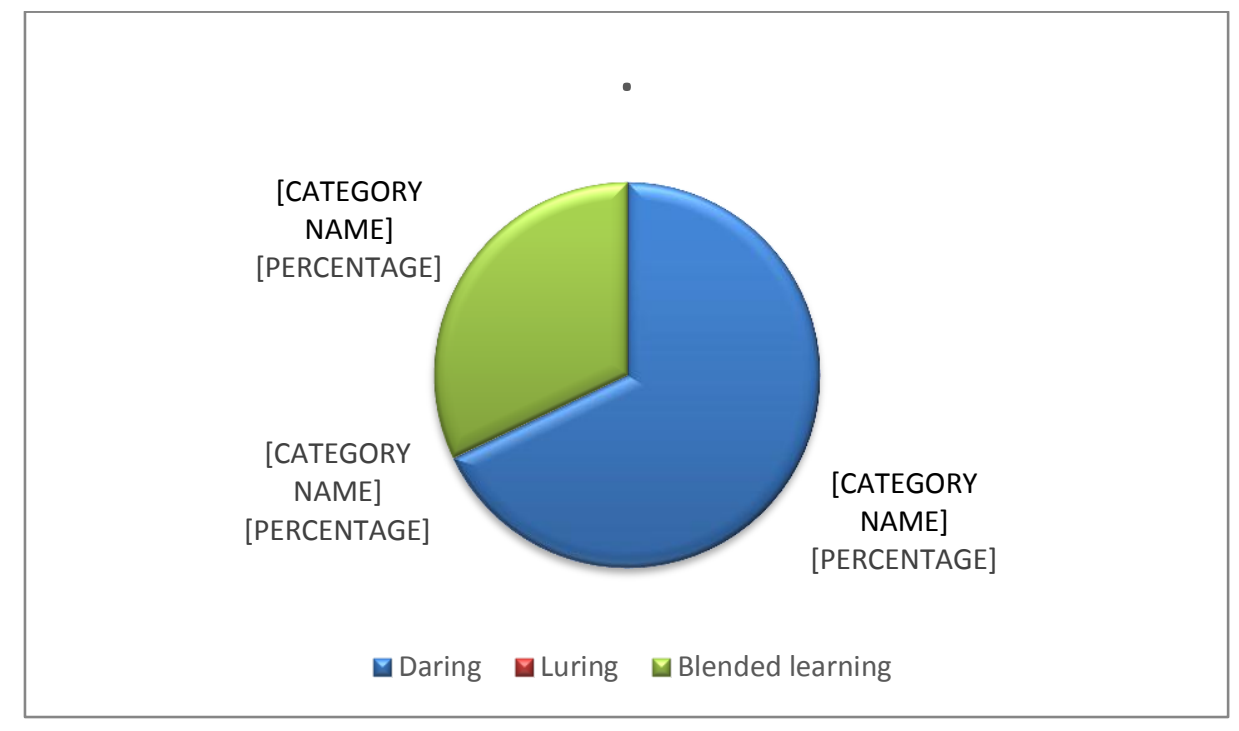

\section{Gambar 2 Proses Pembelajaran Daring di Madrasah Ibtidaiyah}

Sulit rasanya untuk mencapai tujuan pembelajaran saat pandemi COVID-19 terjadi. Kondisi darurat yang terjadi membuat proses pembelajaran tidak dapat berjalan normal seperti biasanya, akan tetapi siswa harus memperoleh pembelajaran yang baik di masa pandemi COVID-19 (Wahyudin, 2020). MI telah melaksanakan proses pembelajaran di masa pandemi COVID-19 sesuai dengan kondisi dan kreativitas masing-masing. Pembelajaran daring dan blended learning merupakan solusi bagi pelaksanaan pendidikan di madrasah selama masa pandemi COVID-19, sehingga siswa, guru, dan orang tua harus mampu beradaptasi dalam penerapan model pembelajaran yang baru (Indriani, 2021). Namun, hikmah dari pandemi COVID-19 yaitu dirasakannya manfaat dari pelaksanaan pembelajaran daring sangat banyak, seperti mencegah penularan vrus Corona, waktu belajar lebih fleksibel, pembelajaran lebih inovatif, kreatif, mandiri, hubungan keluarga lebih dekat, menghargai waktu, dan materi bisa dibaca kembali (Nabila, 2020).

Pemanfaatan tool sebagai daya dukung utama pembelajaran daring terlihat di Gambar 3 sebanyak 57\% guru MI se-Kota Magelang dalam melaksanakan kegiatan pembelajaran daring menggunakan smartphone, sedangkan sebanyak 43\% guru MI se-Kota Magelang dalam menerapkan pembelajaran daring menggunakan laptop. Berdasarkan Gambar 3, terlihat bahwa tool yang digunakan 
dalam proses pembelajaran daring oleh guru MI se-Kota Magelang bervariasi. Keterampilan guru dalam menguasi tool adalah salah satu aspek penting dalam pembelajaran daring sehingga guru dapat melakukan kegiatan belajar mengajar sesuai kemampuannya (Nurdin \& Anhusadar, 2020). Tool dapat dimanfaatkan secara optimal pada saat proses pembelajaran.

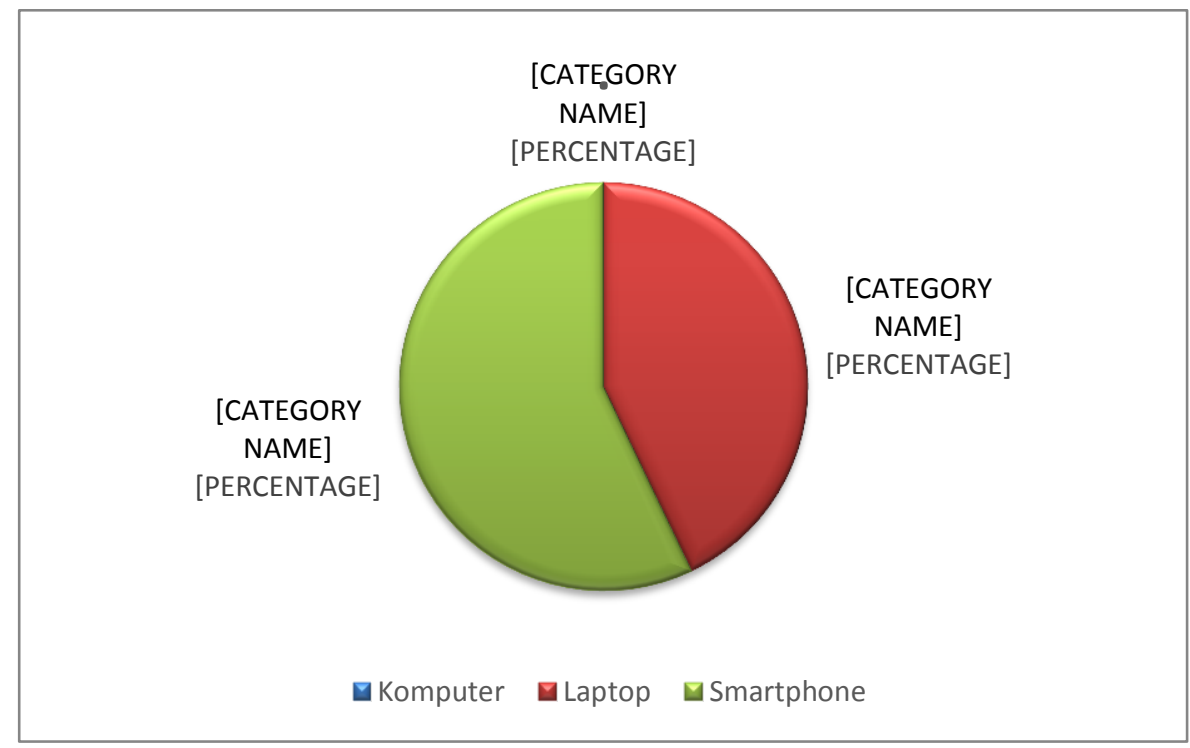

\section{Gambar 3 Tool yang Digunakan dalam Pembelajaran Daring}

Hasil jawaban responden terkait platform yang digunakan dalam pembelajaran daring terlihat pada Gambar 4. Gambar 4 terlihat jelas bahwa sebanyak 85,7\% guru MI se-Kota Magelang menggunakan aplikasi WhatsApp dalam pelaksanaan pembelajaran daring, sebanyak 7,15\% guru menggunakan Google Clasroom, dan yang lainnya mengkombinasikan platform yang digunakan dalam pembelajaran daring. Data di Gambar 4 terlihat jelas penggunaan platform WhatsApp menjadi aplikasi pilihan guru MI se-Kota Magelang karena lebih mudah dalam penggunaanya dan tidak menghabiskan paket data yang besar. Penggunaan WhatsApp lebih mudah dibandingkan dengan platform yang lain, hal tersebut karena perlu adanya bimbingan yang lebih ekstra jika mengajarkan platform selain WhatsApp pada siswa dan orang tua, yang kebanyakan tidak paham untuk mengoperasikannya (hasil wawancara, 2 April 2021). 


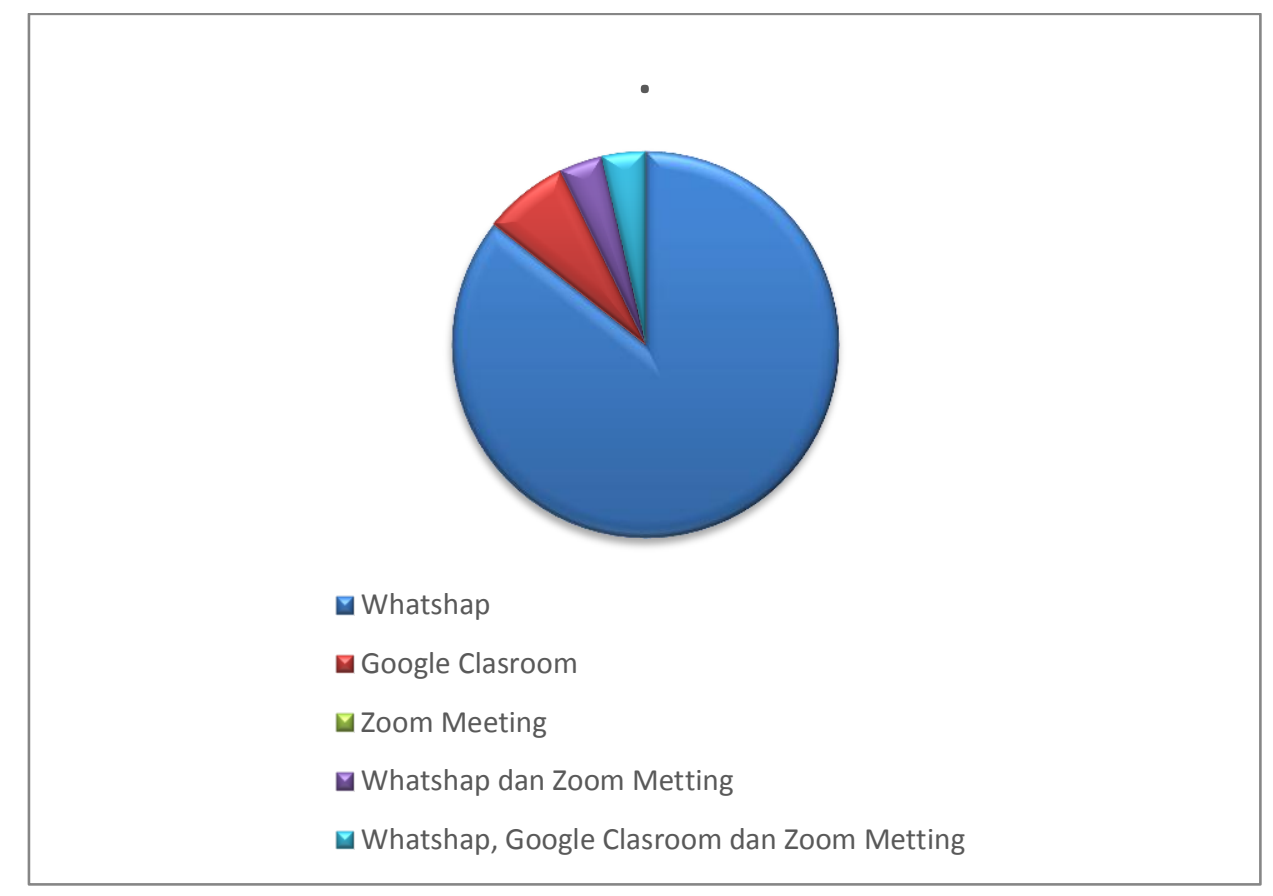

\section{Gambar 4 Platform yang Digunakan dalam Pembelajaran Daring}

Penggunaan WhatsApp oleh guru sebagai media pembelajaran yang mendukung pembelajaran daring dalam penyampaian materi ajar dan mengirim tugas kepada siswa (Putria et al., 2020). Penguasaan platform pembelajaran daring oleh guru di masa pandemi COVID-19 sangat penting, sehingga guru bisa tetap mengajar secara baik dan profesional. Situasi pandemi COVID-19 membuat guru lebih inovatif dan kreatif dalam menyampaikan materi pembelajaran karena tugas dan tanggung jawab guru tidak lepas untuk manghasilkan siswa yang berkarakter dan memiliki kemampuan untuk menguasai ilmu pengetahuan dan teknologi (hasil wawancara, 6 April 2021). Pandemi COVID-19 membuat siswa yang semula belajar dari madrasah beralih menjadi belajar dari rumah. Walaupun belajar dari rumah, siswa tetap belajar layaknya berada di madrasah, akan tetapi perbedaannya pada media yang akan digunakan yaitu menggunakan WhatsApp, Google Clasroom, dan platform lainnya (Yunitasari \& Hanifah, 2020). Saat siswa belajar dari rumah, siswa juga memperoleh materi pembelajaran seperti belajar di madrasah yang membedakan hanyalah jam belajarnya.

Hasil jawaban respons guru terhadap pembelajaran daring terlihat di Gambar 5. Responden menyatakan "setuju" terkait pembelajaran daring dilanjutkan. 
Apabila data responden pada komponen "setuju diteruskan" dilakukan analisis dengan menggunakan rumus rata-rata, maka nilainya adalah $68 \%$. Pembelajaran daring dapat menghemat waktu dan tentunya mencegah penyebaran COVID-19. Guru perlu menyiapkan instrumen pembelajaran baru yang tepat dan sesuai sehingga dapat diterapkan kepada siswa MI (Simanjuntak et al., 2020). Peningkatan kompetensi guru dalam hal teknologi memiliki peran penting untuk menunjang proses pembelajaran daring, sehingga tercapai tujuan pembelajaran (Mar'ah et al., 2020).

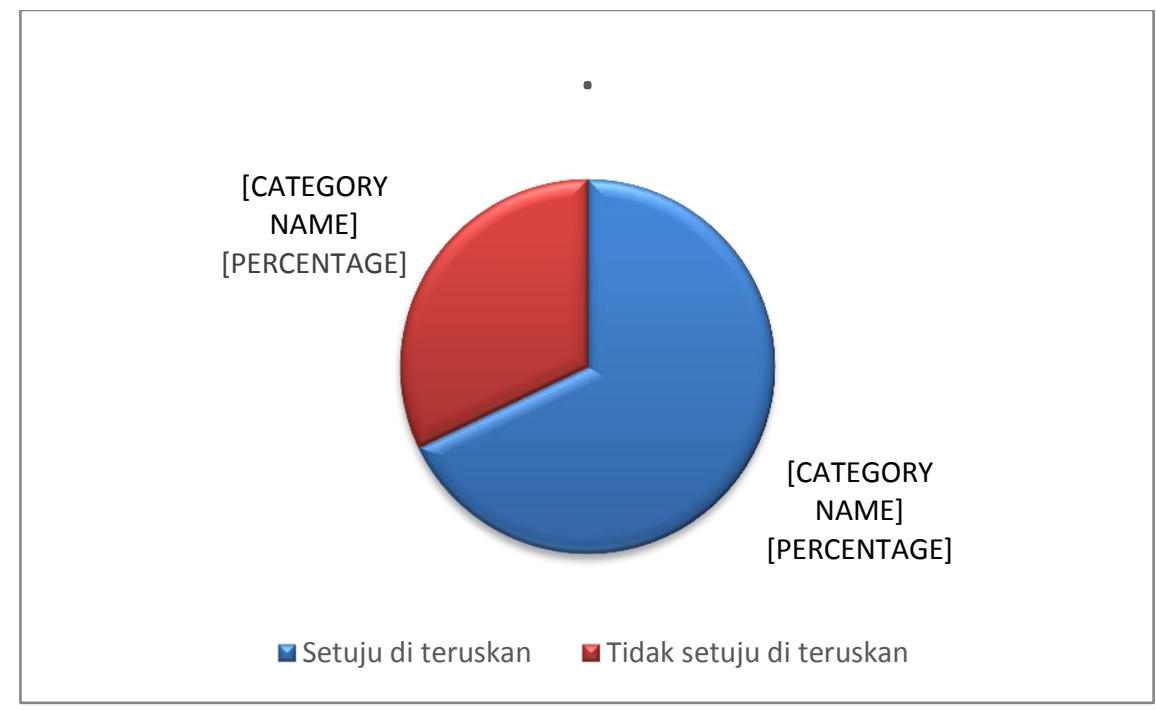

\section{Gambar 5 Respons Guru terhadap Pembelajaran Daring}

Hasil jawaban responden terkait menyusun RPPD dalam pembelajaran daring terlihat di Gambar 6. Berdasarkan Gambar 6, terlihat bahwa 79\% guru MI se-Kota Magelang menyusun RPPD dan 21\% guru MI se-Kota Magelang tidak menyusun RPPD. Berdasarkan hasil tersebut, maka disimpulkan bahwa guru MI telah menyusun rencana pelaksanaan pembelajaran daring dan sesuai dengan capaian pembelajaran. Perubahan pembelajaran dari tatap muka ke daring memengaruhi perubahan RPP yang digunakan. RPPD perlu dipersiapkan untuk pembelajaran daring di Madrasah (Astuti, 2021). Pembelajaran daring memerlukan koneksi internet untuk menghubungkan antara guru dan siswa. Kemampuan guru untuk mempersiapkan RPPD sangat penting untuk peningkatan kualitas pembelajaran sehingga dapat dipertahankan dengan baik (Warsito, 2021). Pembelajaran daring yang dilakukan merupakan solusi pencegahan dari 
penyebaran COVID-19 yang masih berlangsung. Virus Covid sangat mudah proses penularannya melalui sistem pernafasan manusia (Handarini \& Wulandari, 2020).

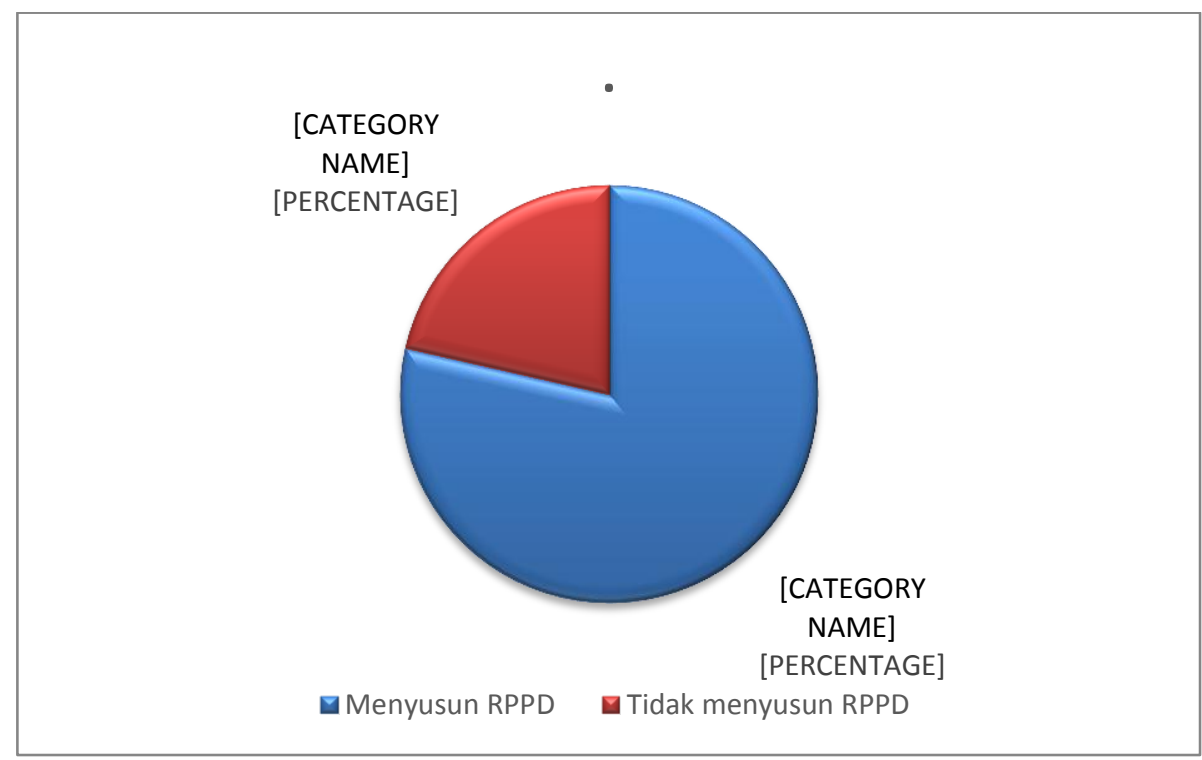

Gambar 6 Menyusun RPPD dalam Pembelajaran Daring

\section{SIMPULAN}

Berdasarkan hasil penelitian, maka disimpulkan: pembelajaran daring di MI se-Kota Magelang selama masa pandemi COVID-19 berjalan secara "efektif"; guru telah menjalankan pembelajaran daring saat pandemi COVID-19; guru dapat menguasai "smartphone" dan "laptop" sebagai tool dalam pembelajaran daring; "WhatsApp" merupakan pilihan utama sebagai media dalam melaksanakan pembelajaran daring; guru "setuju" jika pembelajaran daring dilanjutkan dengan memperhatikan rencana RPPD yang telah dibuat sesuai dengan indikator yang telah terukur sesuai dengan capaian pembelajaran.

\section{DAFTAR PUSTAKA}

Anugrahana, A. (2020). Hambatan, Solusi dan Harapan: Pembelajaran Daring selama Masa Pandemi Covid-19 oleh Guru Sekolah Dasar. Scholaria: Jurnal Pendidikan dan Kebudayaan, 10(3), 282-289. https://doi.org/10.24246/j.js.2020.v10.i3.p282-289.

Astuti, M. (2021). Analisis Efektifitas Penyelenggaraan Pembelajaran Daring di 
Sekolah Dasar pada Masa Pandemi Covid-19. Journal of Integrated Elementary Education, $\quad$ 1(1), 41-49. https://doi.org/10.21580/jieed.v1i1.7224.

Dewi, W. F. (2020). Dampak Covid-19 terhadap Implementasi Pembelajaran Daring di Sekolah Dasar. Edukatif: Jurnal Ilmu Pendidikan, 2(1), 55-61. https://doi.org/10.31004/edukatif.v 2i1.89.

Handarini, O. I., \& Wulandari, S. S. (2020). Pembelajaran Daring sebagai Upaya Study From Home (SFH). Jurnal Pendidikan Administrasi Perkantoran (JPAP), 8(3), 465-503.

Hariyanti, D., Mun'im, A. H., \& Hidayat, N. (2020). Identifikasi Hambatan Mahasiswa dalam Pelaksanaan Pembelajaran Biologi Secara Daring Selama Pandemi Covid-19 di Kabupaten Jember. ALVEOLI: Jurnal Pendidikan Biologi, 1(1), 11-21. https://doi.org/10.35719/alveoli.v1i1.4.

Huzaimah, P., \& Amelia, R. (2021). Hambatan yang Dialami Siswa Dalam Pembelajaran Daring Matematika Pada Masa Pandemi COVID-19. Jurnal Cendekia : Jurnal Pendidikan Matematika, 5(1), 533-541.

Indriani, E. (2021). Analisis Efektivitas Implementasi Pembelajaran Daring Dimasa Pandemi Covid-19 Pada Siswa SMA Kelas X se-Kecamatan Mranggen Mata Pelajaran PJOK. Journal of Physical Activity and Sports (JPAS), 2(1), 1-11. https://doi.org/10.53869/jpas.v2i1.34.

Lesmana, C., \& Arpan, M. (2017). Penerapan Model Pembelajaran Project Based Learning terhadap Kemampuan Psikomotor, Aktivitas Belajar, dan Respon Mahasiswa. Jurnal Pendidikan Informatika dan Sains, 6(1), 8-19. http://dx.doi.org/10.31571/saintek.v6i1.483.

Mar'ah, N. K., Rusilowati, A., \& Sumarni, W. (2020). Perubahan Proses Pembelajaran Daring pada Siswa Sekolah Dasar. Prosiding Seminar Nasional Pascasarjana UNNES.

Marken, M. (2020). Efektifitas Pembelajaran Jarak Jauh (PJJ) selama Pendemi Covid-19 di SDN 21 Sarang Burung Danau Kabupaten Sambas Kalimantan Barat. Jurnal Pendidikan Sains dan Aplikasinya, 3(2), 59-65. http://dx.doi.org/10.31571/jpsa.v3i2.2300. 
Miles, M. B., \& Huberman, A. M. (1994). An Expanded Sourcebook: Qualitative Data Analysis. London: SAGE Publications Ltd.

Nabila, N. A. (2020). Pembelajaran Daring di Era Covid-19. Journal of Chemical Information and Modeling, 01(01), 1689-1699.

Nurdin, N., \& Anhusadar, L. (2020). Efektivitas Pembelajaran Online Pendidik PAUD di Tengah Pandemi Covid 19. Jurnal Obsesi : Jurnal Pendidikan Anak Usia Dini, 5(1), 686-697. https://doi.org/10.31004/obsesi.v5i1.699.

Nurrita, T. (2018). Pengembangan Median Pembelajaran untuk Meningkatkan Hasil Belajar Siswa. Misykat, 3(1), 171-187. http://dx.doi.org/10.33511/misykat.v3n1.171.

Riyana, C. (2019). Produksi Bahan Pembelajaran Berbasis Online. Tangerang Selatan: Universitas Terbuka.

Sii, P., Verawardina, U., Arpan, M., \& Sulistiyarini, D. (2017). Penerapan Model Pembelajaran Inkuiri pada Mata Pelajaran KKPI terhadap Kemampuan Psikomotorik Siswa. Jurnal Pendidikan Informatika dan Sains, 6(2), 166176. http://dx.doi.org/10.31571/saintek.v6i2.642.

Simanjuntak, S. Y., Kismartini, Dwimawanti, I. H., \& Hidayatullah, M. A. (2020). Respons Guru terhadap Kebijakan Pembelajaran Jarak Jauh selama Pandemi Covid-19. Jurnal Ilmiah Pendidikan Citra Bakti, 7(2), 125-136. https://doi.org/10.38048/jipcb.v7i2.108.

Surat Edaran Mendikbud Nomor 4 Tahun 2020 tentang Kebijakan Pendidikan dalam Masa Darurat Penyebaran COVID-19 dalam https://pusdiklat.kemdikbud.go.id/surat-edaran-mendikbud-no-4-tahun2020-tentang-pelaksanaan-kebijakan-pendidikan-dalam-masa-daruratpenyebaran-corona-virus-disease-covid-1-9. Diakses 22 Oktober 2021.

Putria, H., Maula, L. H., \& Uswatun, D. A. (2020). Analisis Proses Pembelajaran Dalam Jaringan (DARING) Masa Pandemi COVID-19 pada Guru Sekolah Dasar. 4(4), 861-872. https://doi.org/10.31004/basicedu.v4i4.460.

Sutini, S., Mushofan, M., Ilmia, A., Yanti, A. D., Rizky, A. N., \& Lailiyah, S. (2020). Efektivitas Pembelajaran Daring dengan Menggunakan E-learning Madrasah terhadap Optimalisasi Pemahaman Matematika Siswa. JRPM 
e-ISSN 2407-1803 | p-ISSN 1829-8702

Copyright (c) 2021 Minzani Aufa, Kanthi Pamungkas Sari https://journal.ikippgriptk.ac.id/index.php/edukasi/article/view/2961 DOI: http://dx.doi.org/10.31571/edukasi.v19i2.2961

(Jurnal Review Pembelajaran Matematika), 5(2), 124-136. https://doi.org/10.15642/jrpm.2020.5.2.124-136.

Wahyudin, A. (2020). Model Pembelajaran Bleended Learning (Model Flipped Classroom) untuk Meningkatkan Efektivitas Pembelajaran IPS pada Masa Pandemi Covid19. Journal: Sudut Pandang, 1(1), 1-23.

Warsito. (2021). Upaya Meningkatkan Kemampuan Guru dalam Menyusun RPP Daring melalui Active Knowledge Sharing. Jurnal Kewarganegaraan, 5(1), 101-106. https://doi.org/10.31316/jk.v5i1.1283.

Yunitasari, R., \& Hanifah, U. (2020). Pengaruh Pembelajaran Daring terhadap Minat Belajar Siswa pada Masa COVID 19. Edukatif: Jurnal Ilmu Pendidikan, 2(3), 232-243. https://doi.org/10.31004/edukatif.v2i3.142. 